УДК 821.82.1.82-14"19"Т.Шевченко

DOI: $10.33402 / \mathrm{ukr} .2020-33-465-479$

\begin{abstract}
Tapac ПАСТУХ
доктор філологічних наук стариий науковий співробітник відділу украӥнської літератури Інституту украӥнознавства ім. І. Крип'якевича НАН Украйни ORCID: https://orcid.org/0000-0001-5606-1441 e-mail:tarpastukh@gmail.com
\end{abstract}

\title{
ШЛЯХИ РЕЦЕПЦІЇ ВІРШІВ ШЕВЧЕНКА
}

Здійснено спробу розглянути герменевтичні принципи, з якими читач має підходити до рецепції поетичних творів Тараса Шевченка. Проведено екскурс у ранню історію сприйняття віршів Шевченка. Розглянуто відгуки таких читачів-критиків, як Григорій Квітка-Основ'яненко, Віссаріон Бєлінскій (Виссарион Белинский), Микола Костомаров, Пантелеймон Куліш, Михайло Драгоманов, що дає змогу простежити, як соціокультурне налаштування критиків впливало на сприйняття поезій Шевченка. Також вказано, що вже в ранній рецепції Шевченкових віршів виокремлено дві провідні тенденції: в одній увага звернена на їхню «правдивість», а у другій - на поетичність. Зазначено, що під «правдивістю» варто розуміти те, що Шевченкова поезія творить образний світ за певними правилами, які їй через автора дає природа; образна ж виразність, композиційна доладність, смислова глибина - ознаки «правдивості». Наголошено на самозначності Шевченкової поезії, що не була відображенням поетової реальності, а в якій у специфічній образній формі «самовиявилися» певні буттєві структури, $і$ вже будучи явленими в образному тексті, ці структури так чи так апелювали до навколишньої дійсності, увиразнюючи та прояснюючи ії окремі фрагменти чи ситуації.

Констатовано, що в мистецтві розуміння існує дві провідні тенденції: перша-читач має зредукувати свій суб'єктивний чинник до мінімально можливого і спрямувати увагу на розуміння твору в його культурно-історичному й авторсько-біографічному контекстах; друга - засвідчує часовість розуміння тексту, де читач не може сприймати твір із позиції авторського або якогось «універсального» часу - його розуміння завжди зроджується із власного, який передбачає свою соціокультурну ситуацію, стан мови, життєву біографію самого читача. Зазначено, що читач повинен збалансувати ці дві тенденції у власній інтерпретації. Вказано, що в широті можливих підходів прочитання «Кобзаря» актуальними $\epsilon$ вивчення мови текстів та явлених у них екзистенційно-буттєвих ситуацій.

Ключові слова: поезія, рецепція, герменевтика, поетика, естетика, екзистенція.

Намір читати «Кобзар» Шевченка висуває на перший план такі запитання: як і $з$ чим підходити до цих віршів? На що в них звертати увагу і як можна розуміти їх загалом? Вони далеко не такі прості, як видаються на перший погляд, адже передбачають усвідомлення як особливостей самих поезій Шевченка, так і загальних законів розуміння писаного тексту. Звичайно, можна й не ставити собі цих запитань, а просто взяти «Кобзар» та почати читати, і тоді в безпосередньому акті сприйняття 
3'являтиметься певне розуміння Шевченкових рядків, фрагментів, цілих віршів. Однак краще, щоб читач приступив до «Кобзаря» із певним усвідомленням того, що можна очікувати від задуманого читання і що взагалі відбувається у процесі рецепції поетичних творів. У такому випадку предметом рефлексій можуть бути не тільки самі Шевченкові образи, а й відповідність чи невідповідність того, чого очікувалося, і того, що насправді було одержано. Крім того, будь-яке наближення до творчості Шевченка вже передбачає певну налаштованість чи, як казав ГансГеорг Гадамер (Hans-Georg Garamer), «передрозуміння». Така налаштованість особливо виразна у випадку з цим автором, адже Шевченко надто відомий у просторі української культури. І це відіграє як позитивну, так і негативну роль - формує певну налаштованість, певне читацьке очікування. Не викликає жодних сумнівів, що практика рефлексування реципієнта щодо своєї налаштованості на читання та щодо самого процесу особистої «зустрічі з текстом» означає кращий, більш адекватний та осмислений рівень сприйняття художнього твору. Пошук відповідних підходів до поезії Шевченка зумовлює мету цієї статті.

Шевченко - це не просто відома чи знакова постать в українській культурі. Він стоїть у центрі українського літературного канону, визначаючи його основи та провідні тенденції ${ }^{1}$. Автор «Кобзаря» представив у скристалізованій формі визначальні складові українського буття. Він довів поетичну мову до найвищого рівня експресії, а також виступив новатором у сфері певних естетичних тенденцій. Шевченко вивів українську мову з того ідейно-естетичного кола, яке окреслили поети-романтики; трансформував фольклорну естетику, зробивши відомі поетичні формули виразниками нових значень; збагатив поезію новими формами й засобами народної мови; явив небачену до того у віршованій формі стихійність письма (3 ритмічними перепадами, «провалами», суттєвим відходом від нормативних приписів віршоскладання); розширив лексичні властивості українського вірша через використання церковнослов'янських і староукраїнських мовних форм, а також словоформ російської та польської мов тощо.

Надзвичайний талант Шевченка був відзначений уже рецензентами перших видань «Кобзаря» (1840) та «Гайдамаків» (1841), серед яких можна згадати імена Ніколая Полєвого (Николая Полевого), Осіпа Сєнковского (Осипа Сенковского), Петра Корсакова (Пётра Корсакова), Свгена Гребінки, Віссаріона Бєлінского 2 . Водночас уже перші рецензіі, а також письмові відгуки в листах Григорія КвіткиОснов'яненка, Пантелеймона Куліша, Осипа Бодянського 3 демонструють відмінне прочитання віршів Шевченка. За показовий приклад можуть слугувати два полярні відгуки - Г. Квітки-Основ'яненка і В. Бєлінского. Перший виявляє беззастережне схвалення віршів поета: «Хтось мудро написав і живо усю правду списав» ${ }^{4}$ (згодом я повернуся до цієї оцінки). У притаманній бурлескно-сентиментальній манері адресант описує свої тілесні відчуття, які супроводжували процес читання: «Волосся в

1 Про це див.: Пастух Т. Шевченковий канон і сучасна українська література. Літакцент. 2014. 24 березня. URL: http://litakcent.com/2014/03/21/shevchenkovyj-kanon-i-suchasna-ukrajinskaliteratura/ (дата звернення: 11.04.2020).

2 Див.: Тарас Шевченко в критиці. Прижиттєва критика (1839-1861)/ за заг. ред. Г. Грабовича. Київ: Критика, 2013. Т. 1. С. 3-34.

3 Див.: Листи до Тараса Шевченка / за ред. В. С. Бородіна. Київ: Наукова думка, 1993. С. 5-25.

4 Там само. С. 5. 
мене на голові, що вже його і не багацько, та і те навстопужилося, а біля серця так щось і щемить, ув очах зеленіє» ${ }^{5}$. В іншому листі Г. Квітка-Основ’ яненко згадує, що читав «Гайдамаків» «декому з наших», то вони аж «поцмакували» від захоплення 6 .

В. Бєлінскій спочатку дав доволі високу оцінку як самим «Гайдамакам», так i їхньому авторові: «П. Шевченко володіє чудовим поетичним даруванням і пише малоросійською мовою чудові вірші. Його “Гайдамаки" - це твір, просякнутий думкою і почуттям, дихає непідробним натхненням і сяє іскрами живої, різноманітної і палкої фантазії. Якби "Гайдамаки” були написані російською, то цю поему варто було б віднести до числа кращих російських поем». А приблизно за місяць в іншому відгуку в тих же «Гайдамаках» він уже не бачить ні поезії, ні сенсу. Натомість російський критик знаходить тут вияви вульгарного смаку, а також відсутність «простоти вигадки і розповіді». Саму сюжетну канву поеми В. Бєлінскій представляє у глузливо-іронічній манері: «Тут є все, що годиться для кожної малоросійської поеми: тут ляхи, жиди, козаки; тут добряче лаються, п’ють, б'ють, палять, ріжуть; ну, звичайно, в антрактах кобзар (адже без кобзаря яка вже малоросійська поема!) співає свої натхненні пісні, без особливого сенсу, а дівчина плаче, а буря гомонить...» ${ }^{8}$. Будь-який адекватний читач не може не подивуватися із цього виразно однобічного, «насмиканого», упередженого представлення «Гайдамаків», яке пропонує провідний російський критик того часу.

Звернімо увагу, що В. Бєлінскій зосереджується не на самій поемі, а на тих iï рисах, які, за його словами, презентують «кожну малоросійську поему». 3 усвідомленням того, що українська література починає розвиватися, набувати більшого значення, російський критик починає різко негативно ставитися до її текстуальних виявів. Особливо його дратують твори, позначені чималим талантом (у чому, як пригадуємо, він сам попередньо зізнавався). В. Бєлінскій швидко усвідомив майбутні наслідки автономізації українського духовно-культурного життя в межах Російської імперії й почав гостро виступати проти перших її виявів. Варто сказати, що про виразно негативне ставлення провідного російського критика до української літератури вже багато написано. Безпосередню логіку міркувань Віссаріона Бєлінского добре реконструював Григорій Грабович (George Grabowicz): «Що найбільше бентежило його, це те, що вона [українська література - T. П.] поставала не за буцімто універсальними, буцімто суто раціональними законами як продукт (надбудова?) певної суспільної структуризації і власне держави, а як вольове, децентралізоване, замалим не стихійне явище, якого за законами, чи пак схемами, якими критик керувався (тобто переінтерпретовував або й вигадував), просто не мало бути; за всією його логікою воно не мало раціонального права на життя. Не маючи окремої просвіченої верстви (адже вся просвічена верства вже давно зінтегрована у всеросійське, імперське суспільство) і не маючи вже (як це йому бачилося) своєі окремої історії, Україна не може (раціонально, на повному серйозі) творити високу літературу, тобто щось, що йде поза утилітарні потреби “літератури для домашнього

\footnotetext{
Листи до Тараса Шевченка... С. 5.

Див.: Там само. С. 9.

7 Белинский В. Гайдамаки. Поэма Шевченка. Тарас Шевченко в критииі. Прижиттєва критика (1839-1861) / за заг. ред. Г. Грабовича. Київ: Критика, 2013. Т. 1. С. 32.

8 Там само. С. 45 .
} 
вжитку" ${ }^{9}$. Іншими словами, у випадку із В. Бєлінскім бачимо подвійну негативну налаштованість: раціоналіста, не схильного сприймати романтичний твір, у якого $€$ своя художня логіка й естетика, і російського шовініста, котрий із позиції «високої» імперської культури виявляє зневажливе ставлення до «низької» культури колонії, небезпідставно передчуваючи, що розвиток останньої приведе до висунення спочатку культурної, а потім і політичної претензії на незалежність.

Натомість Г. Квітка-Основ'яненко не мав такої негативної налаштованості до Шевченкових творів, якою відзначився російський критик. Навпаки, він був схильний позитивно сприймати поезію Шевченка. I не тільки через те, що, ймовірно, серед творів, які надіслав Т. Шевченко, був вірш «До Основ’яненка». Відтак поет міг полестити творчим амбіціям Г. Квітки-Основ'яненка, і той, відповідно налаштований, позитивно сприйняв інші вірші. Такий момент міг бути, але він не відігравав визначальної ролі в цьому випадку. Головне, що в поезіях Т. Шевченка було щось, що викликало у Г. Квітки-Основ'яненка враження, що автор «живо усю правду списав». У цьому короткому й промовистому вислові опорними є дві лексеми-характеристики Шевченкового поетичного письма: воно має властивість «живо» представляти «правду». І тут виникає запитання: що стоїть за цими лексемами? Чому Г. Квітка-Основ'яненко вдався саме до цих слів, щоби висловити свою оцінку поезій Т. Шевченка? Лексема «живо» має такі значення: 'виразно, яскраво, чітко'; 'енергійно, пожвавлено, з пришвидченням темпу'; 'за короткий відрізок часу, швидко' ${ }^{10}$. Лексема «правда» - 'те, що відповідає дійсності; істина'; вислів «усю правду сказати» - це 'розповісти комусь про що-небудь, нічого не приховуючи' ${ }^{11}$. Іншими словами, Г. Квітка-Основ'яненко вказує на те, що саме зображає поезія Шевченка (істину), і як вона це робить (яскраво, енергійно, стисло).

Пізніші читачі та критики Шевченкових творів у різний спосіб підтверджують те, про що писав Г. Квітка-Основ'яненко. Так, М. Костомаров в «Огляді творів, писаних малоросійською мовою» (надрукованому в альманасі «Молодик» за 1843 р., ч. 3) стверджує: «Він [Шевченко - Т. П.] не тільки вигодуваний народною малоросійською поезією, але цілковито оволодів нею, підпорядкував іiї собі і дає їй вишукану, освічену, форму. Риси в зображуваних ним постатях - Катерині, кобзарі, Перебенді, - є тими ж, які нам представляє природа; але разом з тим, в них міститься поезія загальна, така, яка зрозуміла кожному» ${ }^{12}$. Бачимо, що критик також відзначає те, як Шевченко описує дійсність - точно, відповідно до того, якою вона є (наприклад, реалістично зображені кобзарі). Його поетика виростає з українського фольклору і водночас, на думку критика, є більш «вишуканою» та «освіченою», тому ії може «зрозуміти кожен» (М. Костомаров як прибічник культурно-історичної школи дотримується уявлень про висхідний еволюційний розвиток поетичної творчості). Вказівка на те, що автор «Кобзаря» змальовує дійсність

9 Грабович Г. Прижиттєва рецепція Шевченка: становлення національного поета. Тарас Шевченко в критииі. Прижиттєва критика (1839-1861) / за заг. ред. Г. Грабовича. Київ: Критика, 2013. T. 1. C. XXV-XXVI.

${ }^{10}$ Словник української мови: в 11-ти т. / за ред. І. К. Білодіда та ін. Київ: Наукова думка, 1971. T. 2. C. 526.

${ }_{11}$ Там само. 1976. Т. 7. С. 497-498.

${ }^{12}$ Костомаров М. Обзор сочинений, писанных на малороссийском языке. Історія украӥнської літературної критики та літературознавства. Хрестоматія: у 3-х кн. / за ред. П. М. Федченка. Київ: Либідь, 1996. Кн. 1. С. 206. 
такою, якою вона є (відповідно до «природи»), власне, і свідчить про те, що поет являє у своїх творах «правду».

П. Куліш у відомому «Слові над гробом Шевченка» теж наголошує на поетичності та правдивості його віршів. Поетичність пов'язує з особливою мовою поета, адже «уся сила і вся краса нашої мови тільки йому одному одкрилася». Саме мовні властивості визначають поетичність Шевченкових творів. Ця, на перший погляд, тривіальна думка - це насправді одна з визначальних у розумінні основ Шевченкової поетики. За П. Кулішем, здатність мови впливати (дія «сили») та викликати захоплення (чарувати «красою») у поезіях «Кобзаря» доведена до максимального ступеня; і ніхто в цьому не може 3 ним зрівнятися. Також П. Куліш цитує Шевченкові рядки:
Ми не лукавили з тобою,
Ми просто йшли, - у нас нема
Зерна неправди за собою...

Вони для нього - «великий і святий завіт»: «Будь же, Тарасе, певен, що ми його соблюдемо і ніколи не звернемо з дороги, що ти нам проложив єси. Коли ж не стане в нас снаги твоїм слідом простувати, коли не можна буде нам, так як ти, безтрепетно святую правду глаголати; то лучше ми мовчатимем, - і нехай одні твої великі речи говорять людям вовіки і віки чисту, немішану правду» ${ }^{13}$. П. Куліш бачить Т. Шевченка як того, хто подає приклад, як варто «безтрепетно святую правду глаголити». Іншим письменникам треба або слідувати цьому прикладу, або взагалі мовчати - настільки важливе оце «глаголення святої правди».

Отож, бачимо, що вже в ранній рецепції Шевченкових віршів заокреслюються дві провідні тенденції. В одній увага звернена на їхню «правдивість», а в іншій - на поетичність. Із визначенням об’єкта Шевченкової поетики все меншбільш зрозуміло - це ті художні засоби (фонетичного, лексичного, синтаксичного рівнів), завдяки яким поезія сприймається виразно, яскраво, захопливо. Складніше iз визначенням «правдивості» (тому беру це слово в лапки). М. Костомаров, як уже зазначено, під «правдивістю» бачив точність відображення дійсності. Але тут виникає запитання: про яку дійсність ідеться в цьому випадку? Адже, як відомо, $\mathrm{i}$ Катерина, і Перебендя, про яких згадує М. Костомаров, не були реальними постатями. Очевидно, йдеться про якусь іншу дійсність, аніж ту, яка оточувала і поета, і критика. Про неї М. Костомаров каже, що своїм походженням завдячує природі. I знову запитання: а що це за природа? Виходячи з міркувань критика, це - не органічний та неорганічний матеріальний світ у всій сукупності його зв'язків і форм, а те, що породжує суще й дає йому закони. Етимологи простежують зв'язок латинської лексеми nātūra - 'природа природні властивості; характер'; iз nātus 'народжений' i $n \bar{a} s c \bar{l}$ - 'народжуватися' ${ }^{14}$. Іммануїл Кант (Immanuel Kant) у «Критиці естетичної здатності судження» визначає генія так: «Геній-це талант (природне

13 Тарас Шевченко в критиці. Посмертна критика (1861) / за заг. ред. Г. Грабовича. Київ: Критика, 2016. T. 2. С. 110.

${ }^{14}$ Етимологічний словник української мови: в 7-ми т. / за ред. О. С. Мельничука та ін. Київ: Наукова думка, 2004. Т. 4. С. 49 
обдарування), який дає мистецтву правило. Оскільки талант, як природжена продуктивна спроможність художника, сам належить до природи, то можна було б сказати і так: геній - це природжені задатки душі (ingenium), через які природа дає мистецтву правило» ${ }^{15}$. Власне, до цієї творчої природи, що виявляється у здатності поета створювати «те, для чого не може бути дано жодного визначеного правила» (Кант), апелює М. Костомаров; принаймні до цього веде логіка його розмислів.

Іншими словами, Шевченкова поезія не так апелює до реальності, як творить образний світ за певними правилами, які їй дає природа (творче начало Всесвіту) ${ }^{16}$. Образна виразність, композиційна доладність, смислова глибина - ознаки «правдивості» Шевченкової поезії; як і явлені в ній у всій експресії стихійного представлення нові мистецькі «правила» - свідчення поетового генія. Важливо наголосити на самозначності Шевченкової поезії, що не була відображенням його реальності, а в якій у специфічній образній формі «самовиявилися» певні буттєві структури. I вже будучи явленими в образному тексті, ці структури так чи так апелюють до навколишньої дійсності, увиразнюючи і прояснюючи її окремі фрагменти чи ситуації. Варто сказати: те, що тут видається за розрив між реальним та поетичним світами, насправді таким не $\epsilon$. Адже реальна дійсність і поезія Шевченка виходили з одного джерела - природи. Завдяки останній (як універсальному творчому началу) постав і навколишній світ, і поезія як така.

Вже за 15 років після смерті Шевченка М. Драгоманов вказав на те, що «всі, хто бравсь писати про нього, перш усе думали про себе, і кожний повертав Шевченка, як йому на той час було треба, та, глядячи на те, перед ким говорилось про українського кобзаря» ${ }^{17}$. Такому підходу автор праці «Шевченко, українофіли і соціалізм» протиставив інший підхід, у якому необхідно «докладно розсудити об тім, що таке справді Шевченко с а м п о с о бі й у с в і й ч а с ${ }^{18}$. У цьому спостереженні М. Драгоманов означив дві визначальні тенденції у «мистецтві розуміння»; і вони, варто наголосити, становлять протилежні способи читацького наближення до художнього твору. Як стверджує Г.-Г. Гадамер, читач має розуміти твір, виходячи із «самих фактів» (про які говорять тексти), а також із «слововживання епохи й/або автора»; відповідно реципієнт має зректися «довільності [власних - T. П.] осяянь та обмеженості непомітних розумових звичок» ${ }^{19}$. Іншими словами, читач повинен зредукувати свій суб'єктивний чинник до мінімально можливого і спрямувати увагу на розуміння твору в його культурно-історичному й авторсько-біографічному контекстах. У випадку із Шевченком йдеться про відчитання його поезій відповідно до духу доби, у якій жив поет, фрагментів його біографії, стильової течії романтизму, у якій він переважно творив і в яку увів нові

\footnotetext{
${ }_{15}$ Кант I. Естетика / пер. 3 нім. Б. Гавришкова. Львів: Аверс, 2007. С. 143.

16 Владислав Татаркевич (Władysław Tatarkiewicz), зробивши екскурс в історію питання «правди і вигадки в мистецтві», приходить до такого висновку: «... концепція мистецької правди упродовж сторіч, напевно, рухалась од відповідності репрезентованому предметові до відповідності намірам творця» (див.: Татаркевич В. Історія шести понять / пер. 3 пол. В. Корнієнка. Київ: Юніверс, 2001. С. 288).

17 Драгоманов М. Шевченко, українофіли й соціалізм. М. Драгоманов. Літературно-публіцистичні прачі: у 2-х т. Київ: Наукова думка, 1970. Т. 2. С. 7.

18 Там само.

19 Див.: Гадамер Г.-Г. Істина і метод. Основи філософської герменевтики: у 2-х т. / пер. 3 нім. О. Мокровольського. Київ: Юніверс, 2000. Т. 1. С. 248-249.
} 
риси, мовних особливостей того часу, а також тих «фактів», до яких апелював поет. Це, власне, і становить Драгоманову пропозицію помислити Шевченка «самого по собі й у свій час».

Інша тенденція засвідчує часовість розуміння тексту: читач не може сприймати твір із позиції авторського або якогось «універсального» часу. Його розуміння завжди зроджується із власного, який передбачає свою соціокультурну ситуацію, стан мови, коло «фактів», а також життєву біографію самого читача. Тут варто згадати твердження Олександра Потебні: «Будь-яке пізнання, по-суті, $є$ історичним і має для нас значення лише у ставленню до майбутнього» ${ }^{20}$. Один із засновників філософської герменевтики Мартін Гайдеггер (Martin Heidegger) із темпоральності буття виводив «колову структуру розуміння» ${ }^{21}$. Приклад часовості розуміння продемонстрував уже згадуваний Драгоманов, який подивився на романтичні твори Шевченка з філософсько-естетичних позицій позитивізму. Відтак чимало $з$ того, що було прийнятним і важливим для поета-романтика, стало неприйнятним для критика-позитивіста. Наприклад, М. Драгоманов дійшов висновку, що більшість Шевченкових поем «дуже необроблені» 3 мистецького погляду; а «Сон» та «I мертвим, і живим...», на його думку, - взірці «розтріпаності» 22 . Пригадаймо, що подібний закид у браку мистецького смаку Т. Шевченкові робив В. Бєлінскій. Часовість розуміння можна побачити в іншій площині. Кожен, хто хоч трохи цікавиться шевченкознавчими працями, має змогу спостерегти нерідко повторювальний сюжет, коли якийсь дослідник критикує концепції та ідеї своїх попередників як «хибні і невідповідні матеріалові» й відтак дає своє «справжнє» розуміння творчості письменника. Попри психологічний чинник «утвердження себе коштом інших», існують глибші підстави для більш або менш гострої критики попередників. Йдеться, власне, про темпоральність розуміння, яка передбачає також індивідуально-світоглядні конфігурації. Час змінився - змінилося бачення творчості поета, відтак попередні його осмислення вже перестають задовольняти.

У 1986 р. Юрій Шевельов простежив шість основних підходів до творчості Шевченка: «народницький» (Пантелеймон Куліш, Микола Костомаров; згодом Сергій Єфремов, Микола Сумцов), «позитивістичний» (Михайло Драгоманов, Федір Вовк), «націоналістичний» (Степан Смаль-Стоцький, Леонід Білецький), «естетично-формалістичний» (Микола Євшан, Микита Сріблянський, Андрій Ніковський, Павло Филипович), «псевдоісторичний» (радянські шевченкознавці, зокрема Юрій Івакін), «інтегральний» (Григорій Грабович, Богдан Рубчак, Леонід Плющ, Марко Павлишин). Ознаками останнього, за Ю. Шевельовим, є «намагання схопити текст інтегрально - як рух від тексту до особи і знов від особи до тексту, своєрідний психологізм, але психологізм узагальнений, так би мовити. Звідси звернення до міту, переступлення через багато різних табу» ${ }^{23}$. Не можна не помітити симпатії дослідника до цього підходу, що зумовлено, власне, часом і відповідними обставинами. Тут можна припустити, що якби Ю. Шевельов не емігрував під час

${ }^{20}$ Потебня А. А. Эстетика и поэтика. Москва: Искусство, 1976. С. 306.

${ }^{21}$ Див.: Гадамер Г.-Г. Істина і метод... Т. 1. С. 247.

22 Драгоманов М. Шевченко, українофіли й соціалізм... Т. 2. С. 93.

${ }^{23}$ Шевельов Ю. Слово на відкритті шостої шевченкознавчої конференції. Світи Тараса Шевченка. Збірник статей до 185-річчя з дня народження поета. Нью-Йорк; Львів: Наукове Товариство ім. Шевченка, 2001. Т. II. С. 13. 
Другої світової війни за кордон і не дожив до своїх пізніх літ, то представлена картина була б інакшою (якщо би взагалі постала). Подібно з послабленням цензурного тиску й набуттям Україною незалежності змінюються підходи в українському материковому шевченкознавстві. Показовий приклад - поява в 1997 р. монографії Оксани Забужко «Шевченків міф України: Спроба філософського аналізу», виконана в парадигмі власне «інтегрального» підходу.

Варто зауважити, що попри виразні симпатії до зазначеного підходу, Ю. Шевельов не $є$ його цілковитим прихильником. Він виступає за різноманітні наукові переконання та підходи. Головне, щоби всі вони грунтувалися на «власних критичних судженнях», виводили шевченкознавство з інерції, давали змогу по-іншому подивитися на вже зроблене і відкривали «нову сторінку у шевченкознавстві» 24 . Власне в основі цієї методологічної плюралістичності лежить усвідомлення, що жоден метод не універсальний; кожен із них визріває у своєму часі і зі своїм часом відходить. Тут Ю. Шевельов вдається до аналогії із церковною архітектурою в Європі, яка нерідко складається з напластувань фрагментів романського стилю, готики, бароко, рококо, класицизму, конструктивізму - подібно різноманітні підходи у дослідженні творчості Шевченка утворюють напластування в шевченкознавстві. У цій аналогії візуально увиразнено те, що кожен стиль - продукт свого часу; а розвиток архітектури, власне, і складається із напластування різних стилей. Водночас повнота оприявлення стилю - ознака творчої майстерності архітектора. У випадку з науковою діяльністю варто говорити про повноту, вдалість та доцільність застосування методології.

Отож, дослідник опиняється в ситуації, коли необхідно якось узгодити дві засадничі тенденції в інтерпретації: 1) дивитися на текст у соціокультурному часі його постання; 2) сприймати текст із позиції свого часу. Надмірна перевага якоїсь однієї неминуче негативно позначиться на синтетико-аналітичному рівні дослідження. Г.-Г. Гадамер стверджує, що у процесі адекватного розуміння відбувається «злиття горизонтів» автора (тексту) і читача, яке здійснюється через мову, «історичне передання», традицію ${ }^{25}$. «Горизонтом» тут є все те, що може бути побаченим із якогось пункту. Цей «горизонт» рухомий, і завдання «історичного розуміння щоразу містить у собі й вимогу знайти такий історичний горизонт, аби те, що ми хочемо зрозуміти, постало перед нами у своїх власних пропорціях» ${ }^{26}$. У нашому випадку йдеться про необхідність читача вийти - через мову, «історичне передання», традицію - на такий рівень бачення віршів Шевченка, у якому сказане в них набуває відповідних філософсько-естетичних проєкцій. Історичне передання, зазначає Г.-Г. Гадамер, забезпечує певну загальність (а не суб’єктивність) акту розуміння. А історична ситуація, у якій перебуває інтерпретатор, визначає інтерпретаційну проблематику та сегменти актуалізації наявного досвіду в процесі розуміння.

Г.-Г. Гадамер стверджує, що розуміння тексту веде до саморозуміння ${ }^{27}$, адже на фоні «історичного передання» (втіленням якого є текст) увиразнюється власна інтерпретаційна діяльність читача. Сказане підтверджує відома цитата Івана Дзюби: «Шевченка розуміємо настільки, наскільки розуміємо себе - свій час і Україну в

\footnotetext{
${ }^{24}$ Див.: Шевельов Ю. Слово на відкритті...

25 Див.: Гадамер Г.-Г. Істина і метод... Т. 1. С. 273, 275, 351.

${ }^{26}$ Там само. С. 281

27 Див.: Там само. С. 275.
} 
нім ${ }^{28}$. Тобто читацький рівень розуміння себе самого й України як соціокультурного феномена відповідає рівню розуміння творчості Т. Шевченка. 3 другого боку, тексти поета виявляють граничну кристалізацію «історичного передання» та мови. Тому попри історичність (часовість) вони виступають у ролі оптимального каталізатора процесу читацького саморозуміння та мірила фрагментів цього саморозуміння, визначення власної ідентичності тощо. Показово, що І. Дзюба вдається до такої аналогії: у духовному житті українського суспільства Т. Шевченко (його поезія, постать) відіграє роль «системи життєзабезпечення», подібно як хлібо-, водо-, енергопостачання становлять «системи життєзабезпечення» будь-якої людської громади і без яких остання не може існувати ${ }^{29}$. Тексти Шевченка та його життя творять духовну «систему життєзабезпечення» саме завдяки вказаній граничній кристалізації історичного передання та мови. Дзюба також додає, що якщо ми хочемо, щоб поет залишався «системою життєзабезпечення» і для наступних поколінь, то «повинні подбати про те, щоб у Шевченковому слові сприймався Шевченків зміст» ${ }^{30}$. Ці його слова перегукуються із герменевтичною вимогою Г.-Г. Гадамера знайти такий «горизонт», у якому сказане постало б перед читачем «у своїх власних пропорціях». Водночас I. Дзюба вказує на те, що існує потреба продовжувати традицію - не лише передавати тексти поета (лат. traditio - ‘передавання'; лексема trado - 'передавати, вручати з рук у руки' $\left.{ }^{31}\right)$, а й осмислювати їх «в Шевченковому дусі» - суголосно із тим, як це робив їхній автор.

I тут виникає запитання: а що саме 3 «історичного передання» скристалізовано в текстах Шевченка і про що саме промовляє його мова? Т. Шевченко, як уже зазначено, довів поетичну мову до небаченого до того й після того рівня експресії. Після П. Куліша («уся сила і вся краса нашої мови тільки йому одному одкрилася») на це вказувало чимало дослідників творчості Т. Шевченка. Так, І. Франко наголошував на природності, динаміці та широкій амплітуді мови: «В українську поезію він [Шевченко - Т. П.] відразу вносить те, чого в ній до того часу не було - пристрасть, вогонь, захопленість, якусь елементарну силу. ... Це жива людина з багатим душевним змістом, жива енергійна натура, для якої поезія не іграшка, не хизування, але природній і простий вираз почуття, як спів для птахи. Гама його тонів широка: він сумує, падає духом і підіймається, здатний до гніву і погроз і разом з тим до найм'якших і найніжніших почуттів; він мрійник і разом $з$ тим дуже чутливий до запитів дійсності; він веселий, але зовсім без гумористичної жилки, патетичний, але без тіні театральності; він усюди простий і щирий. Не дивно, що його поезія відразу вразила його земляків як якесь одкровення, тим більше, що і зовнішня форма її була уповні національною, а мова, попри всю свою невишуканість, образна, мелодійна і колоритна, блищала всіма красотами рідного мовлення» ${ }^{32}$. На мову віршів Шевченка звертали увагу й закордонні дослідники-славісти. Так Альфред

\footnotetext{
${ }_{28}$ Дзюба І. Тарас Шевченко. Життя і творчість. Київ: Вид. дім «Києво-Могилянська академія», 2008. C. 5.

${ }^{29}$ Там само. С. 6.

30 Там само.

31 Див.: Латинско-Русский словарь О. Петрученко. Москва: Тип-фия Г. Лисснера и А. Гешеля, 1904. С. 652.

${ }^{32}$ Франко I. Южнорусская литература. I. Франко. Зібрання творів: y 50 m. Київ: Наукова думка, 1984. T. 41. C. 121.
} 
Снсен (Alfred Jensen) писав про «мелодійну красу» його поезії, через що ії зовсім не легко перекладати іншою мовою. Шведський славіст звернув увагу на фонічно-ритмічні особливості віршів поета і сказав: «В римах є він [Шевченко - Т. П.] досить ощадний, а артистичними і штучними будовами вірша як станци, терцини або сонета, зовсім не занимався. А прецінь в поезіях Шевченка лежить ритмічний рух, який ніколи не мучить, ані не є монотонним, а брак римів заступають обильно ассонанції, аллітерації і ріжнородне метрум» ${ }^{33}$.

Марієтта Шагінян (Мариэтта Шагинян) монографію «Тарас Шевченко» розпочинає із розділу про поетику, яку розглядає насамперед із погляду мовних властивостей віршів. Дослідниця пише: «Поетика Шевченка не може бути виведена ні 3 фольклорності як такої, ні з голої майстерності як такої, а є результатом безперервного творчого розширення народного мовлення, отриманого з молоком матері, як першопочатковий “дар слова”, - розширення його завдяки змістові, завдяки передачі в ній найтонших відтінків думки і настрою, пристрасних політичних і філософських узагальнень. 3 кожним віршем Шевченко вдосконалює для народу його зброю культури - мову, робить ніжну, м'яку, “сімейну” мову селянина, прилаштовану до простого селянського вжитку, відточеною і гострою, вирішує в межах цієї мови драматичні і соціальні колізії, розгортає історичні полотна, філософствує, знущається, мріє, плаче, мне іiі як глину в руках, доводить іiї тонкощі, життєздатність, придатність для боротьби, для будь-якої передачі на будь-якій “хвилі”. Навіть у перших своїх, ніби тільки “фольклорних” піснях він веде цю боротьбу, хоча б тим, що використовує стійкий ритмічний стандарт (коломийковий, колядковий вірш) для зовсім незвичних, не властивих цьому віршу настроїв (в цьому значенні чудовим $€$ “Перебендя", зразок глибоко індивідуального вирішення чисто народної ритміки)» ${ }^{34}$. Далі робить чимало цікавих і глибоких спостережень із ракурсу мовних властивостей його віршів - їхніх ритмічних візерунків; явлених у них алітерацій і асонансів, енжамбеманів, стильових властивостей («високої» та «низької» мови) тощо.

Подібно Ю. Шевельов звертається до мови Шевченкових творів 1860 р., що дає змогу проникливо схарактеризувати низку ознак поетики «Кобзаря». Так, безпрецедентне поєднання церковнослов'янізмів, вульгаризмів та словосполучень, типових для народних пісень, виводить із контексту однієї епохи; у читача створюється враження, що він перебуває водночас усюди й ніде; відтак драматичний конфлікт набуває універсальності; у плані емоцій така контрастність виводить читача з рівноваги, змушує сприймати те, що він читає не просто як ще один літературний твір, а «крик болю, зойк оголених нервів» ${ }^{35}$. Простеження ритмічного візерунка віршів веде до висновку, що Шевченко дає «читачеві можливість уловити певну схему, певну лінію (чи то у віршовій структурі, чи в будові речення), водночас не даючи цій схемі зматеріалізуватися. Це основа постійного конфлікту між літературною формою і свавіллям поетичного генія» ${ }^{36}$. Крайнє спрощення мови, притаманне останньому року творчості поета, у плані зовнішніх показників та незвичайно

\footnotetext{
${ }^{33}$ Єнзен А. Тарас Шевченко. Життя українського поета. Літературна студія / пер. 3 нім. І. Мандюка. Перемишль: Друкарня «Кноллєр і Син», 1921. С. 58.

${ }^{34}$ Шагинян М. Тарас Шевченко. Москва: Гос. изд-во худож. лит-ры, 1946. С. 15.

${ }^{35}$ Шерех Ю. Пороги і запоріжжя. Література. Мистецтво. Ідеології: у 3-х т. Харків: Фоліо, 1998. T. III. C. 32.

${ }^{36}$ Там само. С. 31.
} 
насиченого використання семантичних нюансів слова веде до появи особливого поетичного жанру - «вірша-мініатюри» ${ }^{37}$.

Як бачимо, увага до мови поета може багато сказати про його поетику, естетику, а також - вироблення ідейно-смислових тенденцій. Поезія народжується зі специфічно організованої мови; і кожен великий поет (пригадаймо кантівське визначення генія) творить свої правила ії організації. Наперед їх передбачити не може ніхто, зокрема й сам поет. Але постфактум, коли вірш уже написаний, можна спробувати хоча б частково описати й осмислити ці закони (зрозуміло, що осягнути вповні таємниці творення не вдасться нікому). Бачення того, що нового поет створив в образному слові, увиразнюється на фоні менш чи більш віддаленої поетичної традиції. Також важливий безпосередній розгляд слова - його семантично-стилістичних ознак на фонетичному, морфологічному, лексичному, синтаксичному рівнях. Тут виникають запитання: які слова творять поетичний світ Шевченка? Як поет (порівняно зі звичним слововживанням) в одних випадках посилює їхнє виражальне значення, в інших - видозмінює його? Як задіюється мова у творенні тропів поета? Загалом прочитання віршів Шевченка з увагою до їхньої мови творить широкі можливості для розуміння його поетики, естетики та поетичного світу загалом. Багатоманіття і різноплановість підходів, власне, сприятимуть глибшому розумінню дуже непростого з погляду поетики світу «Кобзаря». Гарольд Блум (Harold Bloom) у відомій монографії «Західний канон: книги на тлі епох» стверджує, що увійти в канон «можна лише завдяки естетичній могутності, котру визначає амальгама мовної фігуративної майстерності, оригінальності, пізнавальної сили, знань та поетичного красномовства» ${ }^{38}$. Естетична могутність Шевченка постає 3 мови, тому лінгвістичне прочитання важливе в наближенні до таємниць його творчого генія.

Поезія твориться з мови і через образи апелює до буттєвих структур, екзистенційних ситуацій та станів. Тому поряд із мовним прочитанням постає необхідність відчитання поезій Шевченка в контексті наявності в них структур, що промовляють про певні визначальні буттєві ситуації, екзистенційні стани тощо. М. Гайдеггер вважав, що поетична мова - той магічний інструмент, який відновлює «свідомість нашого буття» ${ }^{39}$. Німецький філософ стверджував, що людина у світі - в ньому і тільки в ньому - «або реалізує себе через драматичну та пошукову самосвідомість, себто стає автентичною, або виявляє байдужість до самої себе і перетворюється на безіменну, безлику людину» ${ }^{40}$. Власне, відновлення «свідомості нашого буття» у віршах Шевченка становить ще один важливий напрям відчитання. I в ньому окреме місце посідає лінія простеження самореалізації поета через «драматичну та пошукову самосвідомість».

Буттєво-екзистанційна проблематика в поезії Шевченка вимальовується дуже широко: від вияву колективної волі народу до буття до вияву індивідуальної волі окремої особи; від осмислення буттєвих проблем минулого та теперішнього до профетичних візій майбутнього. Також ця проблематика обіймає моральний,

${ }_{37}^{37}$ Шерех Ю. Пороги і запоріжжя... С. 37.

${ }^{38}$ Блум Г. Західний канон: книги на тлі епох / пер. $з$ англ. під заг. ред. Р. Семківа. Київ: Факт, 2007. С. 36.

39 Див.: Фізер І. Філософія літератури / наук. ред. В. Моренця. Київ: НаУКМА; Аграр Медіа Груп, 2012. С. 26.

${ }^{40}$ Там само. С. 25. 
естетичний і релігійний способи існування. Тобто тут перед читачем постають широкі можливості у виборі й актуалізації тої чи тої проблематики. Однак він, маючи право вибору, повинен сягнути такого відчитання, щоб зображуване постало «у своїх власних пропорціях», що можливе за умови актуалізації відповідних фрагментів історико-культурного досвіду та належному - самостійному, відкритому, критичному, вдумливому - його тлумаченню. У тому, на чому саме з Шевченкової поезії реципієнт зупинить свою увагу й що саме з духовно-культурного спадку актуалізує, і виявиться читацька «налаштованість».

Від перших письмових відгуків про Шевченкову поезію і до останніх досліджень автори актуалізували різні складові екзистенційно-буттєвого поля «Кобзаря». Одні звертали більшу увагу на колективну націєформаційну проблематику поетових творів, інші - на проблематику авторського особистого та творчого становлення, ще інші - на його морально-етичних поглядах, ще інші - на естетичних переконаннях митця і так далі. Деякі дослідники намагалися визначити наскрізні лексичні «формули» Шевченкового світу. Так, Дмитро Чижевський зазначає, що все поетичне думання Шевченка чітко концентрується навколо кількох основних думок-понять: «Слово», «Правда», «Слава» ${ }^{41}$. Свген Сверстюк у такому випадку говорить про «Особу», «Свободу», «Долю», «Офіру» ${ }^{42}$. А Іван Дзюба - «Славу», «Слово», «Думу», «Волю», «Добро» ${ }^{43}$. Як бачимо, попри певний перегук у визначенні цих важливих лексичних «формул», кожен із дослідників означує своє коло важливих екзистенційно-буттєвих концептів творчості поета. Ймовірно, що приклад самого Шевченка, який написав триптих «Доля», «Муза», «Слава», де сконцентровано означив три екзистенційно-буттєві лінії свого життя, спонукав вказаних авторів і собі вдатися до подібних лексичних означень. Але водночас зведення певного екзистенційно-буттєвого пласту до одного слова-формули означає і граничну концентрацію проблеми в одній лексемі, i ймовірність ії широкого різнобічного опрацювання. Тут варто знову згадати М. Гайдеггера, який казав, що саме мова (слово) «дає ім'я сущому, і завдяки такому йменуванню вперше спроваджує суще у слово і явище» ${ }^{44}$. Знову ж таки варто наголосити, що від читача вимагається тонке відчуття мови, належної компетентності в засвоєнні «історичного передання», а також нешаблонного, неупередженого, чіткого мислення. У такому випадку відбудеться відповідне усвідомлення «саморозкриття мови» поета, коли вона виявляє суще, «спроваджуючи його у слово і явище».

Соціокультурна ситуація в останні два століття стрімко змінилася: від патріархальної колонізованої Малоросії часів Шевченка до сучасної України, у якій в дивовижно-примхливий спосіб напластувалися явища та тенденції пострадянського суспільства (що обстоює незалежницьку державну позицію) до глобалізації, цифрової епохи; постмодерний, модерний та патріархальний досвіди тощо. Але за всіх цих карколомних змін перед людиною постає одна й та ж екзистенційна проблематика.

${ }_{41}^{41}$ Чижевський Д. Історія української літератури від початків до доби реалізму / літ. ред. Ю. Шереха-Шевельова. Нью-Йорк: УВАН у США, 1956. С. 441.

42 Див.: Сверстюк Є. На святі надій: Вибране. Київ: Наша віра, 1999. С. 321-368.

43 Див.: Дзюба I. Тарас Шевченко. Життя і творчість. Київ: Вид. дім «Києво-Могилянська академія», 2008. С. 618-663.

${ }_{44}^{44}$ Див.: Фізер І. Філософія літератури / наук. ред. В. Моренця. Київ: НаУКМА; Аграр Медіа Груп, 2012. С. 32. 
Від найдавніших часів і до сьогодні вона опиняється перед неуникненним вибором: або «реалізувати себе через драматичну та пошукову самосвідомість» (і в такому випадку стати автентичною особистістю), або «виявляти байдужість до самої себе» (i тоді перетворитися на безлику людину-шаблон).

Цей екзистенційний вибір визначає, на мій погляд, актуальне наближення до поезії Шевченка. У який спосіб Шевченко постав як автентична особистість? Як розгорталася його «драматична і пошукова самосвідомість»? Яку екзистенційно-буттєву проблематику він означував перед самим собою та своїм народом у власному поетичному слові? Спроба відповісти на ці запитання має походити з мови його творів, передбачати головну увагу до поетики тексту. У такому випадку обидві складові слова - змістова й експресивна - не будуть обділені увагою.

Отже, варто зазначити, що увага до екзистенційно-буттєвої самореалізації Шевченка-поета - це свідчення модерного наближення до текстів «Кобзаря». Модерного в габермасівському значенні «незавершеного проекту», який триває і далі, і для якого притаманні «живе» проживання сучасного, туга за «неспоганеним й бездоганним» теперішнім, зв’язок із «класикою», а також прагнення справжнього особистого досвіду...

\section{REFERENCES}

1. Belinskyi, V. (2013). Haidamaky. Poema Shevchenka. In H. Hrabovych (Ed.), Taras Shevchenko v krytytsi (Vol. 1, p. 32.). Kyiv: Krytyka [in Russian].

2. Bilodid, I. K. (Ed.). (1971). Slovnyk ukrainskoi movy: v 11-ty t. (Vol. 2). Kyiv: Naukova dumka [in Ukrainian].

3. Blum, H. (2007). Zakhidnyi kanon: knyhy na tli epokh (R. Semkiv, Ed.). Kyiv: Fakt [in Ukrainian].

4. Borodina, V. S. (Ed.). (1993). Lysty do Tarasa Shevchenka. Kyiv: Naukova dumka [in Ukrainian].

5. Chyzhevskyi, D. (1956). Istoriia ukrainskoi literatury vid pochatkiv do doby realizmu (Yu. Sherekha-Shevelova, Ed.). New York: UVAN u SSHA [in Ukrainian].

6. Drahomanov, M. (1970). Shevchenko, ukrainofily i sotsializm. In M. Drahomanov. Literaturno-publitsystychni pratsi: u 2-kh t. (Vol. 2, p. 7). Kyiv: Naukova dumka [in Ukrainian].

7. Dziuba, I. (2008). Taras Shevchenko. Zhyttia i tvorchist. Kyiv: Vyd. dim «KyievoMohylianska akademiia» [in Ukrainian].

8. Fizer, I. (2012). Filosofiia literatury (V. Morenets, Ed.). Kyiv: NaUKMA; Ahrar Media Hrup [in Ukrainian].

9. Franko, I. (1984). Yuzhnorusskaia literatura. In I. Franko. Zibrannia tvoriv: $u$ 50 t. (Vol. 41, p. 121). Kyiv: Naukova dumka [in Russian].

10. Gadamer, H.-G. (2000). Istyna i metod. Osnovy filosofskoi hermenevtyky: u 2-kh t. (O. Mokrovolskyi, Trans.). (Vol. 1, pp. 248-249). Kyiv: Yunivers [in Ukrainian].

11. Hrabovych, H. (2013). Pryzhyttieva retseptsiia Shevchenka: stanovlennia natsionalnoho poeta. In H. Hrabovych (Ed.), Taras Shevchenko v krytytsi. (Vol. 1, pp. 25-26.). Kyiv: Krytyka [in Ukrainian].

12. Hrabovych, H. (Ed.). (2013). Taras Shevchenko v krytytsi. (Vol. 1). Kyiv: Krytyka [in Ukrainian]. 
13. Hrabovych, H. (Ed.). (2016). Taras Shevchenko v krytytsi. (Vol. 2). Kyiv: Krytyka [in Ukrainian].

14. Kant, I. (2007). Estetyka (B. Havryshkov, Trans.). Lviv: Avers [in Ukrainian].

15. Kostomarov, M. (1996). Obzor sochinenii, pisannykh na malorossiiskom yazyke. In P. M. Fedchenko (Ed.), Istoriia ukrainskoi literaturnoi krytyky ta literaturoznavstva. Khrestomatiia (Vol. 1, p. 206). Kyiv: Lybid [in Russian].

16. Latynsko-Russkyi slovar O. Petruchenko. (1904). Moscow: Typ-fiia H. Lissnera i A. Heshelia [in Russian].

17. Melnychuk, O. S. (Ed.). (2004). Etymolohichnyi slovnyk ukrainskoi movy: v 7-my t. (Vol. 4). Kyiv: Naukova dumka [in Ukrainian].

18. Pastukh, T. (2014, Berezen 24). Shevchenkovyi kanon i suchasna ukrainska literatura. Litaktsent. Retrieved from http://litakcent.com/2014/03/21/shevchenkovyj-kanoni-suchasna-ukrajinska-literatura/ [in Ukrainian].

19. Potebnia, A. A. (1976). Estetika i poetika. Moscow: Iskusstvo [in Russian].

20. Shahynian, M. (1946). Taras Shevchenko. Moscow: Hos. izd-vo khudozh. lit-ry [in Russian].

21. Sherekh, Yu. (1998). Porohy i zaporizhzhia. Literatura. Mystetstvo. Ideolohii (Vol. 3 ). Kharkiv: Folio [in Ukrainian].

22. Shevelov, Yu. (2001). Slovo na vidkrytti shostoi shevchenkoznavchoi konferentsii «Svity Tarasa Shevchenka». In Zbirnyk statei do 185-richchia z dnia narodzhennia poeta (Vol. 2, p. 13). New York; Lviv: Naukove Tovarystvo im. Shevchenka [in Ukrainian].

23. Sverstiuk, Ye. (1999). Na sviati nadii: Vybrane. Kyiv: Nasha vira [in Ukrainian].

24. Tatarkevych, V. (2001). Istoriia shesty poniat (V. Korniienko, Trans.). Kyiv: Yunivers [in Ukrainian].

25. Yenzen, A. (1921). Taras Shevchenko. Zhyttia ukrainskoho poeta. Literaturna studiia (I. Mandiuk, Trans.). Peremyshl: Drukarnia «Knollier i Syn» [in Ukrainian].

Taras PASTUKH

$\mathrm{PhD}$, Senior Researcher at the

Department of Ukrainian Literature

I. Krypiakevych Institute of Ukrainian Studies of the

National Academy of Sciences of Ukraine ORID: https://orcid.org/0000-0001-5606-1441

e-mail: tarpastukh@gmail.com

\section{THE WAYS OF SHEVCHENKO'S POEMS RECEPTION}

The author of the article makes an attempt to consider the hermeneutic principles according to which the reader should approach the reception of Taras Shevchenko's poetic works. He makes an excursus into the early history of the perception of T. Shevchenko's poems and considers the responses of such readers and critics as H. Kvitka-Osnovianenko, V. Belinskyi, M. Kostomarov, P. Kulish, M. Drahomanov. This allows him to trace how certain socio-cultural predispositions of critics determined the perception of T. Shevchenko's poetry. He also notes that already in the early reception of T. Shevchenko's poems, two leading tendencies are outlined. One draws attention to their «truthfulness» and the other to their 
poetics. «Truthfulness» should be understood as the fact that T. Shevchenko's poetry creates a figurative world according to certain rules that nature gives it through the author. Figurative expressiveness, compositional accuracy, semantic depth are the signs of «truthfulness» of T. Shevchenko's poetry. It is essential to emphasize the self-importance of T. Shevchenko's poetry, which was not a reflection of the author's reality, but in which the specific structures of existence «manifested» themselves in a specific figurative form. And already being «manifested» in the figurative text, these structures somehow appealed to the surrounding reality, expressing and clarifying its individual fragments or situations. There are two leading trends in the art of understanding. The first one is that the reader should reduce his subjective factor to the possible minimum and turn his attention to understanding the work in its cultural-historical and author-biographical contexts. Another one indicates the temporality of understanding the text; the reader cannot perceive the work from the standpoint of the author's time or some «universal» time. His understanding is always determined by his own time, which presupposes his socio-cultural situation, the state of language, the reader's life biography. The reader must balance these two tendencies in his own interpretation. There are two important tendencies in the variety of possible approaches to reading the «Kobzar»: to study the language of texts and the existential and ontological situations that arise in them.

Keywords: poetry, reception, hermeneutics, poetics, aesthetics, existence. 


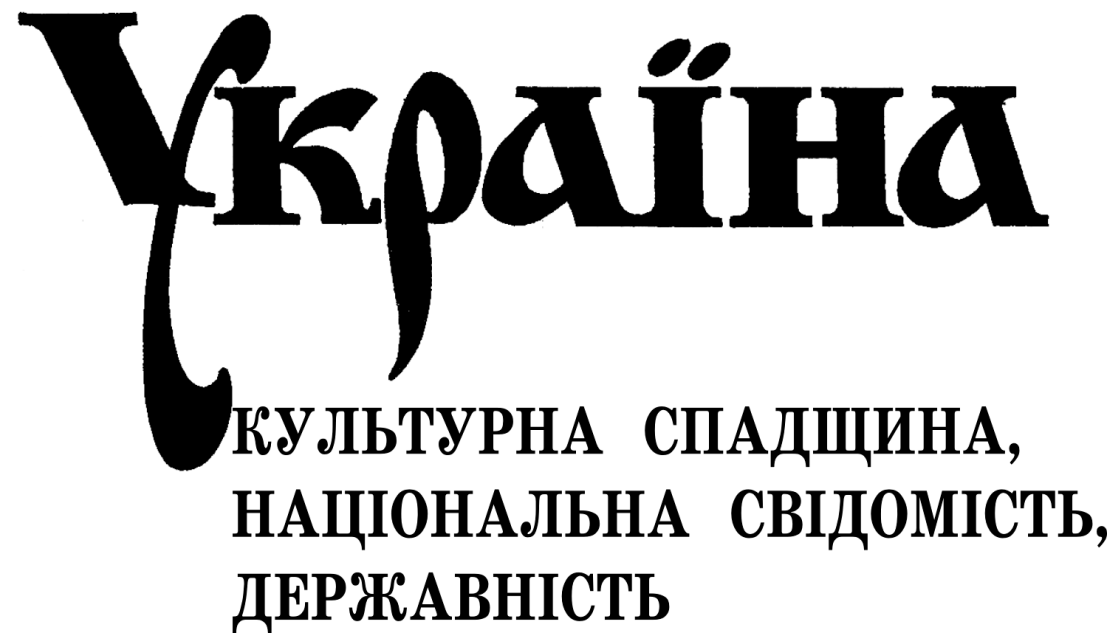

$\frac{2020}{33}$ 
Україна: культурна спадщина, національна свідомість, державність / гол. ред. Ігор Соляр; НАН України, Інститут українознавства ім. І. Крип'якевича. Львів, 2020. Вип. 33. $540 \mathrm{c}$.

Збірник об'єднує студії з історії, мовознавства та літературознавства.

Статті історичного блоку розкривають актуальні проблеми історії України, а також містять розвідки про відомих людей та їх значення у формуванні української державності.

Мовознавчі студії репрезентують українсько-угорську наукову співпрацю, аналіз мовних явищ за матеріалами пам'яток XVI-XVIII ст. та за діалектними джерелами, а також дослідження проблеми інтеграції науково-технічного прогресу (психолінгвістичний аспект).

Дослідження з літературознавства зосереджені довкола аналізу підручників з української літератури XIX століття в університетській системі, особливостей зображення подій Другої світової війни у прозі Росії, США й Угорщини XX століття, а також дослідження поезії - віршів Шевченка та урбаністичних віршів Георга Гайма та Богдана Ігоря Антонича.

Ukraine: Cultural Heritage, National Consciousness, Statehood / Ed. Ihor Soliar; NAS of Ukraine, I. Krypiakevych Institute of Ukrainian Studies. Lviv, 2020. Vol. 33. 540 p.

The collection unites studies in history, linguistics, and literary studies.

Articles of the historical section reveal current problems in Ukraine's history and contain research about famous people and their importance in forming Ukrainian statehood.

Linguistic studies represent Ukrainian-Hungarian scientific cooperation, analysis of linguistic phenomena based on the materials of the 16th-18th centuries and dialect sources, and research on the problem of integration of scientific and technological progress (psycholinguistic aspect).

Research on literary studies focuses on the analysis of textbooks on Ukrainian literature of the 19th century in the university system, the features of the events of World War II in the prose of Russia, the USA, and Hungary of the 20th century, as well as a study of poetry - poems by Shevchenko and urban poems by George Heim and Bohdan Ihor Antonych.

Рекомендувала до друку вчена рада

Інституту українознавства ім. І. Крип’якевича НАН України

(протокол № 9 від 03.12.2020 р.)

ГОЛОВНИЙ РЕДАКТОР

Соляр Ігор Ярославович, д.і.н., проф. (Україна)

ЗАСТУПНИК ГОЛОВНОГО РЕДАКТОРА

Романюк Михайло Васильович, к.і.н. (Україна)

РЕДАКЦІЙНА КОЛЕГІЯ:

Акіллі Алессандро (Achilli Alessandro), $\mathrm{PhD}$ (Australia)

Борчук Степан Миколайович, д.і.н., проф. (Україна)

Газдаг Вільмош (Gazdag Vilmos), $\mathrm{PhD}$ (Україна)

Даниленко Андрій (Danylenko Andriy), PhD, prof. (США)

Золтан Андраш (Zoltán András), dr hab., prof. (Угорщина)

Литвин Микола Романович, д.і.н., проф. (Україна)

Мозер Міхаель (Moser Michael), dr hab., prof. (Австрія)

Муравський Олег Іванович, к.і.н., с.н.с. (Україна)

Надрага Марта Степанівна, к.і.н., с.д. (Україна)

Пастух Тарас Васильович, д.філол.н., доц. (Україна)

Рембішевська Дорота Кристина (Rembiszewska Dorota Krystyna), dr hab., prof. (Польща)

Ситник Олександр Степанович, д.і.н., проф. (Україна)

Ястремська Тетяна Олександрівна, к.філол.н., с.н.с. (Україна)

ISSN 2223-1196

(C) Інститут українознавства ім. І. Крип'якевича НАН України, 2020 


\section{MICT}

\section{ІСТОРИЧНІ СТУДІї}

Актуальні питання української історії ..................... 3

Паршин Ілля. Маловідома згадка про грамоту Луцького єпископа від 1319 року . . . . . . . . . . . . . . . . . . . . . . 3

Войтович Леонтій. Стільсько: між фактами і вигадками . . . . . . . . 13

Пашук Володимир. Греко-католицьке духовенство - важливий соціальний чинник формування товариства «Просвіта» . . . . . . . . . . . 38

Кондратюк Костянтин, Коцюмбас Ореста. Академічна гімназія

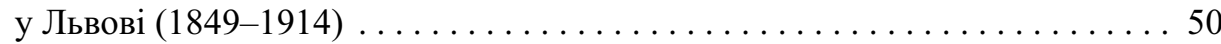

Руда Оксана. Роль політичної партії «Мізрахі» в розвитку єврейського приватного шкільництва у міжвоєнній Польщі . . . . . . . . . . 69

Chotary Juriy. Ilona Zrínyi, the symbol of freedom and courage . . . . . . . . 81 Пагіря Олександр. Від співпраці до ворожнечі: протистояння Карпатської Січі та чехословацьких органів безпеки на зламі (1938-1939) . . . . . . 90

Ільницький Василь, Батюк Тарас. Боротьба радянських репресивнокаральних органів проти підрозділів тактичного відтинку 22 «Чорний ліс» (1946-1947) . . . . . . . . . . . . . . . . . . . . . . . . . .111

Артимишин Юлія. «Закерзоння» як концепт: лінія-кордонтерен-втрачений регіон?

Боднар Галина. «Постійно відчували цензуру і відповідну планку над собою»: Львівський університет імені Івана Франка в 1970-х середині 1980-х років (структура, викладачі, кадрова політика) . . . . . . 157

Піх Олег. Геополітичні розбіжності як чинник відносин Польщі та Pociï (1994-2004)

Артимишин Павло. Харківські угоди 2010 року: візії політичних, медійних та експертних середовищ в Україні ................... 194

Krasivskyi Orest, Pidberezhnyk Nadiia. Problems of nation-building processes in Ukraine at the present stage . . . . . . . . . . . . . . . . . 214

Попко Сергій. Військово-політична співпраця України з НАТО: особливості імплементації програм співробітництва (кінець XX початок ХХІ століття). . . . . . . . . . . . . . . . . . . . . 222

Матіїв Юлія. Соціальна політика в дискурсі політичних партій на позачергових виборах до Верховної Ради у 2014 році. . . . . . . . . . . 234

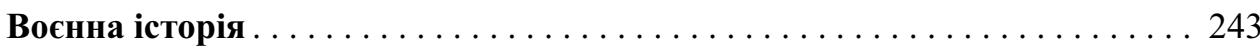

Підшибякін Сергій. Іловайська трагедія 2014 року в дискурсі української громадської думки 
Полтавець Юрій. Особливості навчального процесу

в Національній академії сухопутних військ імені гетьмана Петра Сагайдачного на сучасному етапі . . . . . . . . . . . . 260

Постаті ......................................... 270

Патер Іван. Іван Пулюй - український патріот, політик, державник . . . . . . 270

Сова Андрій. Освітньо-виховна діяльність Івана Боберського в Канаді. . . . . 294

Каменцев Денис. Публіцистична діяльність Володимира Сальського . . . . . 306

Галів Микола, Огар Анна. «Член ОУН» Варвара Степанівна Журбенко:

доля репресованої вчительки (за матеріалами архівно-

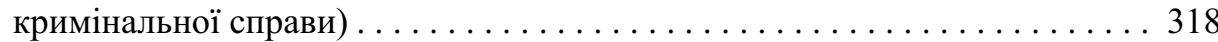

Кравець Наталія. Архівно-слідча справа Василя Проходи

як історичне джерело . . . . . . . . . . . . . . . . . . . . . . . . . 331

Костишин Роман. Громадсько-політична діяльність

Володимира Кохана в 1920-1960-х роках . . . . . . . . . . . . . . . . . . . . . 342

Романюк Михайло. Життєвий шлях Лицаря Срібного хреста

заслуги УПА Івана Червака («Дністрового»). . . . . . . . . . . . . . . . . . . 352

\section{МОВОЗНАВСТВО}

Барань Єлизавета, Барань Адальберт. Внесок Іштвана Удварі

в реабілітацію наукової спадщини Антонія Годинки . . . . . . . . . . . . . . . . 364

Осінчук Юрій. Церковнослов’ янські запозичення в лексичній системі

української мови XVI-XVII століть . . . . . . . . . . . . . . . . . . . . . . . 379

Ястремська Тетяна. Картина світу і концепт:

проблема (пере)осмислення. . . . . . . . . . . . . . . . . . . . . . . . . . . . . . . 394

Мех Наталія, Мех Олег. Інформаційно-техногенний фактор і людина:

психолінгвістичний аспект . . . . . . . . . . . . . . . . . . . . . .411

\section{ЛІТЕРАТУРОЗНАВСТВО}

Генц Адріана. Історія літератури чи філологічні студії: підручники

з української літератури ХІХ століття в університетській системі . . . . . . 422

Барань Адальберт. Особливості зображення подій Другої світової війни

у прозі Росії, США й Угорщини ХХ століття (за романами Василя

Гроссмана «Життя і доля», Джеймса Джонса «Віднині і повік»,

Імре Кертеса «Знедоленість») . . . . . . . . . . . . . . . . . . . . . . . 433

Шкраб'юк Петро. У житті й боротьбі - разом (чотири сильветки про незвичайних жінок України) . . . . . . . . . . . . . . . . . . . . . 448

Пастух Тарас. Шляхи рецепції віршів Шевченка . . . . . . . . . . . . . . . . 465

Гаврилів Тимофій. Місто в модерністичній поезії. Урбаністичні вірші

Георга Гайма та Богдана Ігоря Антонича . . . . . . . . . . . . . . . . . . . . . . . . . . . 480 


\section{ОГЛЯДИ ТА РЕЦЕНЗІї}

Мочернюк Наталія. [Рец.]: «Живий живе гадає!»: творча спадщина і чин Івана Іванця $з$ погляду XXI століття [на кн.]: Іван Іванець (1893-1946). Стрілецькі мемуари, творча спадщина / Упоряд. А. Яців і Р. Яців; вст. сл.: П. Гринчишин; наук. ред. і авт. вст. ст. д.і.н. М. Литвин. Львів, 2019. 476 с.: іл................................ 494

Голик Роман. [Рец.]: Львівська Ставропігія XVIII - початку XX століття: консервативна організація перед викликами модерності [на кн.]: Киричук О., Орлевич I. Львівський Ставропігійський інститут (1788-1914). Роль у суспільно-політичному, культурному та релігійному житті українців Галичини / НАН України, Ін-т українознавства ім. І. Крип'якевича; Львівський музей історії релігії. Львів: Логос, 2018. 288 с............. . 499

Тараніна Богдана. [Рец. на кн.]: Максим Яременко. Перед викликами уніфікації та дисциплінування: Київська православна митрополія у XVIII столітті. Львів: Вид-во УКУ, 2017. 272 с. (Серія «Киӥвське християнство», т. 4)................................ 503

Приступа Євген. [Рец. на]: Сова А. Іван Боберський: суспільно-культурна, військово-політична та освітньо-виховна діяльність: монографія; Інститут українознавства імені Івана Крип'якевича НАН України; Львівський державний університет фізичної культури імені Івана Боберського; Центр незалежних історичних студій. Львів, 2019. 512 с. . . . . 512 Міщанин Василь. [Рец. на]: Вегеш М.М., Віднянський С.В. Августин Волошин - «батько карпатоукраїнського народу». Київ: Парлам. вид-во, 2020. 472 с. + Іл., ім. пок. . . . . . . . . . . . . . . . . . . . . . . . . . . . 516

Голик Роман. [Рец.]: Освіта для нації: нова праця про міжвоєнну Галичину [на кн.]: Руда О. Національно-освітня політика урядів Польщі щодо населення Галичини в 20-30-х роках XX століття: реалізація та рецепції: монографія / Національна академія наук України, Інститут українознавства ім. І. Крип'якевича. Львів, 2019. 802 с. . . . . . 526

ЮВІЛЕї

Реєнт Олександр. Honeste vivere, alterum non laedere, suum cuique tribuere . . 530 Ястремська Тетяна. Слово про Вчителя: до ювілею Павла Юхимовича Гриценка. . . . . . . . . . . . . . . . . . . . . 533 